\title{
WRITTEN EXPRESSION IN ENGLISH FOR SPECIFIC PURPOSES THROUGH BLOGGING AND COOPERATIVE LEARNING
}

\author{
Salvador Montaner-Villalba \\ Universitat Politècnica de València, Spain \\ E-mail: smonvil@idm.upv.es
}

\begin{abstract}
This paper explores the use of blogging as a tool to enhance written expression in English for Specific Purposes and, to be more concrete, in the field of Administration and Management within the Cooperative Learning Approach. The learners who participated in this experiment had B1 level English according to the Common European Framework of Reference for Languages (CEFR). The experiment took place in the educational context of vocational training at a post-compulsory state vocational school in the region of Valencia, Spain. The learners who participated in this experiment were studying the first year of Vocational Training Administration and Business Management during the academic year 2018-2019. The sample was formed by 23 learners who, aged between 25 and 45, participated only in the treatment group. The research questions explore how blogging can be utilized to help learners improve their ESP written production within the Cooperative Learning Approach. The action research model is employed to analyze the quantitative outcomes from this experiment.
\end{abstract}

Key words: English for Specific Purposes, blogging, cooperative learning, written competence

\section{INTRODUCTION}

This research emerged because of the need to better the quality and competence of English for Specific Purposes (ESP) written production by Spanish learners in their first academic year of the Higher Grade of vocational training from the perspective of the Cooperative Learning Approach. This paper is thus framed within the employment of educational technology, in this case, blogging, as a tool for learning English as a foreign language and, specifically, English for Specific Purposes within active educational methodologies, such as the Cooperative Learning Approach. In addition, this research is a response to the lack of publications related to blogging when teaching English as a Foreign Language through the inclusion of active educational methodologies (MontanerVillalba, 2019b) in vocational training. However, it must be said that there is significant empirical research (Campbell 2003, 2004, 2005; Carney 2007, 2008, 2009a, 2009b; Ducate and Lomicka 2005; Fellner and Apple 2006; Godwin-Jones 2003; Jons and Nuhfer-Halten 2006; Pinkman 2005) on blogging in EFL in university settings.

Submitted July $21^{\text {st }}, 2020$, accepted for publication October $10^{\text {th }}, 2020$ 


\section{AIMS}

This research aims to examine whether EFL learners improved their ESP written competence from the perspective of the Cooperative Learning Approach through blogging in the online platform WordPress (https://wordpress.com). It was hypothesized that blogging would help learners improve their ESP written production (Fellner and Apple 2006; Murray and Hourigan 2008) within the Cooperative Learning Approach. At this current research, we aimed to verify whether ESP learners improved their written competence through the use of blogs, in which they had to write their own business plan taking into consideration the postulates of the Cooperative Learning approach. Although blogging, in its primary meaning, implies informal diary-style entries or posts, the novelty of this research was to analyse whether ESP learners could create their own business plans with the aid of the blogs by enhancing written competence in the English language.

\section{LITERATURE REVIEW}

\subsection{Information and Communication Technologies \& ESP}

With regard to applying ICT to teaching ESP, some relevant publications have been based on work in different educational contexts within the University. For example, Lázaro, Pena and Vitalaru (2009) present a qualitative study on teaching English within the field of law as well as translation, through a wiki. Their results showed that there was still a need to explore new methods to define tasks and assess students' contributions. Wikis may be beneficial for improving both collaborative writing and creating glossaries. In her study, Martín-Monje (2010) found that the integration of ICT in an ESP course was not only useful to teachers, who became facilitators within the language learning process, but also helped learners to improve the foreign language that they were learning. In addition, Ghomari (2015) conducted a qualitative research study that investigated how ICT influenced teaching and learning ESP at the Preparatory School of Economic Sciences, Commerce and Management of Oran in Algeria. Preliminary results revealed that the implementation of ICT in this ESP course assisted teachers to identify the necessary strategy to overcome both psychological and pedagogical obstacles. In another study, Akills, Konoplianyk and Pryshupa (2019) explored how students studying civil engineering perceived the implementation of ICT in the ESP classroom through a student survey. Their results revealed that students, particularly those from the treatment group, had significantly improved in comparison to those who participated in the control group. However, little research on ICT in the ESP course has been carried out within the field of vocational training or post-compulsory secondary education and non-university education (MontanerVillalba, 2016, 2017, 2019a, 2019b).

\subsection{Blogging in the ESP Classroom}

In this section the state-of-the-art related to blogging applied to teaching Languages for Specific Purposes will be described. It is worth mentioning that there is scarcely any empirical research related to blogging applied to teaching English for Specific Purposes in the educational context of vocational training (Montaner-Villalba, 2016, 2017, 2019a) and, to be more specific, there are few publications focusing on blogging within the Taskbased Learning Approach in vocational training (Montaner-Villalba, 2019b). However, 
empirical research on blogging within the ESP classroom is more common in universities (Murray and Hourigan 2008; Pinkman 2005; Bran 2009; Awada and Ghaith 2014; Patel 2015). For example, Murray and Hourigan (2008) explored blogging with learners, studying languages and technology. The results showed that a balance had to be achieved between offering certain topics and creating a learning context based upon real life so as to help learners become more active within their learning experience. In her study, Pinkman (2005) showed that blogs were beneficial to learners since they were motivated to utilize the English language due to interaction with, and feedback from, both colleagues and educators. However, some students seemed to be more interested in improving their oral skills rather than their written competences through the use of blogs. Moreover, Bran's (2009) research highlighted the usefulness of edublogs in an ESP course in the field of International Relations, as they allowed the students to create meaningful content. Also, interaction between educators and students was key, implying that students became motivated during the intervention.

More recently, Awada and Ghaith (2014) explored blogging as a tool to help learners improve their writing skills in the field of Law. Results showed that the blog gives an authentic learning context to develop not only writing, but also other skills. In addition, Patel (2015) focused on blogging in an engineering course at a governmental Engineering College at Gujarat Technological University. Outcomes proved that blogging in this ESP course was, as a whole, satisfactory for students, permitting them to interact while blogging: this student interaction was the best part of the experiment, and involved other tools, such as Facebook and Twitter.

Nevertheless, little research has been published on blogging within the ESP classroom in the educational context of Vocational Training and, thus, non-university education. Regarding this kind of publication, Montaner-Villalba (2016) explored blogging through quantitative data in a first-year technical English course CFGS Diseño y Amueblamiento. The results revealed that learners notably improved their ESP writing skills as well as technical vocabulary related to this field. In this same experiment, Montaner-Villalba (2017) concluded that, as for the written competence, the outcomes did not improve at the end of this qualitative research whereas, on the other hand, the results improved with regard to ESP reading competence and technical vocabulary. Thirdly, Montaner-Villalba (2019a) analysed the rank of outcomes, that is, the difference between the largest and smallest values, of written production in a technical English course through blogging. These results showed that ESP written competence improved notably. Finally, MontanerVillalba (2019b) explored blogging in an online ESP course with the inclusion of ProjectBased Learning. From the outcomes given, the author was able to conclude that ESP written competence improved notably during the study.

\subsection{Cooperative Learning}

Blogging in this study is done through the Cooperative Learning Approach. Relevant literature on this approach focuses on its practical application in the classroom (Kagan 2009; Pujolàs 2017). The Cooperative Learning Approach aims to organize the various activities within the classroom to transform them into a social experience. Kagan $(1995,2009)$ defines it as a teaching methodology characterized by forming groups in a heterogeneous manner with respect to their age and educational level. Positive interdependency occurs, but it is necessary to enhance adequate communication within the group to allow members to understand that the main purpose is to carry out diverse tasks in a collaborative manner. Considering that these 
principles of the Cooperative Learning Approach must be fulfilled, the teacher should have a clear procedure to obtain a specific result. Cooperative learning offers potential for the development of communicative skills, group work and thinking flexibility (Gómez-Pezuela 2007; Hernández-Sellés, González-Sanmamed, and Muñoz-Carril 2014).

The practical use of the Cooperative Learning Approach as well as its assessment (Johnson and Johnson 2016) acquires special importance here. For this reason, the Cooperative Learning Approach cannot be conceived without technology, as materials and information sources must be diverse, and must break space and time barriers. Although the most widely used digital collaborative resource is Wikipedia, other online tools, such as blogs and social networks, for instance, are also employed. In this line, blogging permits the learners to take part in a wide variety of digital activities, such as creating written texts, or audio in the case of audioblogs, which enable collaborative learning, team learning and more online interaction by learners (Domingo-Coscolla, Sánchez-Valero, and Sancho-Gil 2014; Sevillano and Vázquez 2011).

At this point, it is important to offer a concise state-of-the-art on writing skills in English within the Cooperative Learning approach. On the one hand, empiric research (Mahmoud, 2014; Ghufron \& Ermawati, 2018) took place at tertiary university. Mahmoud (2014) proved that the learners' scores in writing were slightly higher for the post-test than the pre-test. Ghufron \& Ermawati (2018), in their case study research, showed that Cooperative Learning was successful in helping learners improve their EFL written skills. On the other, empiric research (Nair \& Sanai, 2018; Hertiki \& Juliati, 2019) focused on EFL written competence within the Cooperative Learning approach at A-level. Nair \& Sanai (2018) showed, from the outcomes obtained in both the quantitative as well as the qualitative data, that the cooperative learning approach helped EFL learners improve their writing skills. Additionally, Hertiki \& Juliati (2019), in their action-research study, determined that cooperative learning is key to improve writing skills in English.

As for the ICT to enhance English written competence within the said approach, Aghajani \& Adloo (2018) explored the potential of Telegram to enhance ESP written competence. These authors proved that the treatment group showed slightly higher outcomes in the posttest writing than the control group and, at the time, when comparing both groups, there were significant differences regarding variables such as content, organization, grammar, vocabulary and spelling. Regarding blogging, Montaner-Villalba (2020a) found out that the use of blogs to promote EFL writing skills at Secondary Education was successful while, on the contrary, Montaner-Villalba (2020b) showed, in his quantitative research at A-level, that there was neither a significant improvement nor a deterioration. At this current research, we aim to verify whether blogging helped ESP learners improve their written competence within the Cooperative Learning approach at Vocational Training. Since there is not much empiric research focused on this issue, this paper offers worth.

The focus of this study is, on the one hand, to evaluate the correctness and competence of the written English of vocational training learners and, on the other hand, to test whether using blogging will have a positive impact on students' competence in written production in ESP. The following research question is established: 1. Does blogging help learners improve written production in ESP within the Cooperative Learning Approach? 


\section{METHODS}

\subsection{Sample}

Twenty-three learners, in the first year of the Higher Grade (VET) in Administration and Management during the academic year 2018-2019, participated in the experiment. The learners were chosen for an experimental study. All 23 learners participated in the experiment (there was no control group for this study). Learners were aged between 25 and 45. After an initial test (Section 5.1), designed to determine students' previous knowledge, we established that their level of English was B1 in the case of the youngest learners and between $\mathrm{A} 1$ and $\mathrm{A} 2$ for the oldest learners, according to the Common European Framework of Reference for Languages. This difference of level is due to learners' own educational contexts. Normally, the youngest learners in Vocational Training have recently finished studies at university while the oldest learners (aged 45) are people who probably do not have higher studies. In both cases, these learners in Vocational Training are usually unemployed people who enrol in a Vocational Training course with the aim to search for a job upon finishing the studies.

\subsection{Didactic Treatment}

This study took place during the academic year 2018-2019, commencing in the first term, 2018 and finishing in the second half of May, 2019. During this period, learners performed the intervention in the computer cluster in the school. Learners participated in at least six 55-minute sessions each in the three different terms of the academic year. Therefore, a total of eighteen sessions were addressed in the experiment.

At the beginning of the academic year in the second week of September coinciding with the beginning of the academic year 2018-2019, the learners took a pre-test to assess their EFL written production, EFL reading comprehension and, in general terms, some grammar and vocabulary, which they were supposed to have learnt at previous levels. However, in this research we will only focus on digital written production taking into consideration the ESP perspective. Learners had to introduce themselves professionally in this pre-test. Moreover, they were asked to explain why they were studying Administration in vocational training. In this same week, the study was explained to students (4.4). In the meantime, we focused four sessions on explaining to students how the online platform Word Press works. Informed consent by learners was obtained.

Next, the first digital written task on blogging took place from the first week of October to the first week of December, 2018. In this phase of the experiment, learners were required to begin writing their business plan through their corresponding blogs. Students, in groups of 4, wrote versions of this business plan in different periods corresponding to the three terms. However, before they commenced writing this first draft of the business plan, we had noticed from the pre-test that the results of both grammar and vocabulary were not as satisfactory as was initially expected. Therefore, we thought that it was very adequate to offer learners four reinforcement sessions, as input, each, with the aim of assisting them to improve their ESP digital written competence while blogging for the second task.

Then, in the second week of January 2019, students commenced the second main online written task which had to be finished by the second week of March 2019. In the second digital writing task, students had to write a second draft of their business plan from the first term, taking into consideration the feedback given by the instructor. 
Next, the third digital written task was carried out during April and May 2019. Taking into consideration feedback received by the both the EFL teacher as well as the expert teacher on Business, the students were required to make the appropriate changes to the business plans in their corresponding blogs and finish writing their final versions. However, given the poor outcomes obtained in the content variable of the second digital writing task, we decided it would be appropriate to offer students, as input, five sessions focused on training students how to write their business plans, firstly, in their mother tongue and, secondly, in English. This was done with the aid of the instructors who were business experts. This sort of input possibly helped learners to improve their ESP written competence while blogging and, thus, to obtain better results in the third digital written task.

\subsection{Research Tools}

Before explaining the research tools used in this work, it is important to note that the action-research model was chosen for this study since the author of this current work fulfilled a double role, as both teacher and researcher. Taking this into consideration, it must be highlighted that this is a quantitative study. The different research tools used in this study are now presented. Firstly, we used the pre-test or initial test, to collect quantitative data. Secondly, three different written tasks were employed (Section 4.2). Lastly, we used the post-test to collect further quantitative results. There were, thus, a total of five tasks throughout the experiment. The diverse tasks took place at different moments to coincide with the three terms during the academic year 2018-2019 so that the pre-test was done before commencing the experiment. The first task was completed during the first term, the second task took place during the second term, the third task was done in the third term and, lastly, the post-test was developed after finishing the experiment. The quantitative outcomes of the research were obtained from the said ESP activities with the ultimate purpose of verifying changes in learners' written ESP production.

\subsection{Variables}

The dependent variables are the marks from the corresponding tasks, while the independent variables are classified into: 1) Writing process; and 2) Final product. In this research, we emphasized the final product. Since this paper is focused on ESP written expression, we should distinguish within the final product the following variables (Shehadeh 2011): 1) Content of the text; 2) Organization and structure of the text; 3) Grammar; 4) Vocabulary; 5) Spelling. In correlation with this, the rubrics utilized to assess these variables cover presentation, cohesion and coherence, grammar, vocabulary and spelling (which is considered as part of vocabulary learning). As for the content, students were required to write their own business plan in blog format during the experiment. This business plan had to be written in the corresponding blogs with adequate cohesion and coherence, that is, as a well-organized text. Students were asked to use specific vocabulary from the field of Administration and Management in order to write their business plan in a digital form. Regarding spelling, they were just required to check that there were no spelling mistakes while blogging, which is indeed important regardless of whether it is an ESP course or a proficiency course.

To evaluate this ESP written competence while blogging and, in particular, the different variables, mentioned above, which configure the final product, a basic descriptive statistics analysis through Microsoft Office Excel was carried out. Marks were given, individually, to 
learners for each rubric, mentioned above. The marks on each rubric were validated by introducing in Excel the average obtained from each rubric, and then the total average of each task was calculated. This was done similarly for each task of this intervention. The average of each rubric was calculated with the ultimate purpose of obtaining the total average for each digital task, so that we could observe and analyse how the different outcomes evolved throughout the whole experiment from the graphs obtained. The written assignments were only rated by the teacher-researcher of this study, implying, thus, that there could not be interrater reliability while evaluating. These variables were assessed through traditional marking from the Spanish educational system by the teacher who conducted this current research. Grade A varies between 9 and 10, grade B is between 7 and 8 , grade C is 6 , grade D is 5 and, finally, less than 5 is a fail, which means that learners will not pass either their different subjects within the official curriculum or the different variables of this current experiment, explained above.

\subsection{Research Procedures}

In table 1 the different procedures, as well as their corresponding descriptions and, also, the different moments along the procedures, can be observed:

Table 1 Procedures, Moments, and Descriptions

\begin{tabular}{|c|c|c|}
\hline Procedures & Timetable for the tasks & Descriptions \\
\hline Pre-test & Beginning first term & Pre-test takes place. \\
\hline $\begin{array}{l}\text { Presenting } \\
\text { experiment }\end{array}$ & $\begin{array}{l}\text { First term-second week } \\
\text { of September }\end{array}$ & $\begin{array}{l}\text { Teacher presents experiment, explains aims, } \\
\text { methodology, and timeline. } \\
\text { Digital written tasks are distributed }\end{array}$ \\
\hline $\begin{array}{l}\text { Beginning } \\
\text { experiment }\end{array}$ & $\begin{array}{l}\text { Between last week in } \\
\text { September and first } \\
\text { week in October }\end{array}$ & $\begin{array}{l}\text { Four sessions are focused on explaining how } \\
\text { Word Press functions. }\end{array}$ \\
\hline $\begin{array}{l}\text { Experiment } \\
\text { takes place }\end{array}$ & $\begin{array}{l}\text { First, second and third } \\
\text { term }\end{array}$ & $\begin{array}{l}\text { The online written tasks take place in the } \\
\text { computer cluster of the school. } \\
\text { The teacher guides and helps learners } \\
\text { throughout the whole process, either physically } \\
\text { or via e-mail. }\end{array}$ \\
\hline Post-test & $\begin{array}{l}\text { At the end of the } \\
\text { academic year, having } \\
\text { finished the experiment }\end{array}$ & Final test takes place. \\
\hline
\end{tabular}

\section{RESULTS}

\subsection{Pre-test}

Firstly, the pre-test will be analyzed. In the graph below, the average for the results of the pre-test can be seen. 


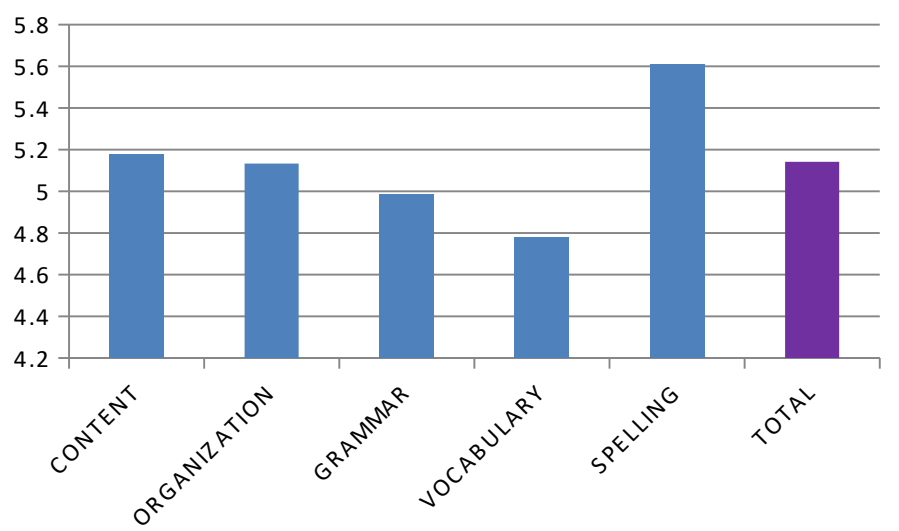

Fig. 1 Average outcomes of pre-test

Students were able to spell words correctly, even though their vocabulary was below the passing threshold (spelling is usually regarded as part of learning vocabulary). Regarding the grammar variable, even though the scores were slightly better than for vocabulary, learners did not seem to have a good command of English grammar and, more precisely the specialised constructions which can be found in Business English. On the other hand, it is curious to observe that the scores for both the coherence and the cohesion of pre-test writing were better than for grammar and vocabulary, although this aspect of writing had not been taught previously to the test. Lastly, regarding the content of the pre-test writing, students managed to obtain scores above the passing threshold.

\subsection{Three Main Digital Production Tasks}

\subsubsection{First Written Task}

Below, the outcomes from the three digital writing tasks will be analysed. In the graph below, the average of the results from the first task can be seen.

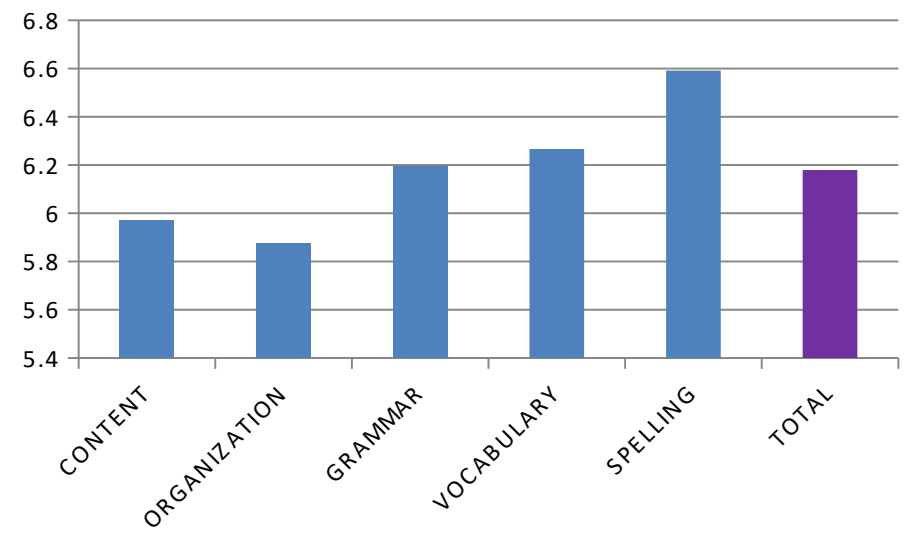

Fig. 2 Average outcomes of first written task 
In this task - as was also the case in the pre-test - students obtained high scores for spelling. However, as it can be seen in the graph, learners obtained much better scores for vocabulary on this first written task than in the pre-test. Regarding the grammar, students also improved here in comparison with the pre-test. If we compare the results of the organization variable between the pre-test and this first digital writing task, we can observe that learners also wrote their business plan in a more cohesive and coherent manner. Finally, as for the content of this writing, a slight improvement occurred in comparison with the pre-test.

\subsubsection{Second Written Task}

The outcomes of this second digital writing task can be observed in the figure below.

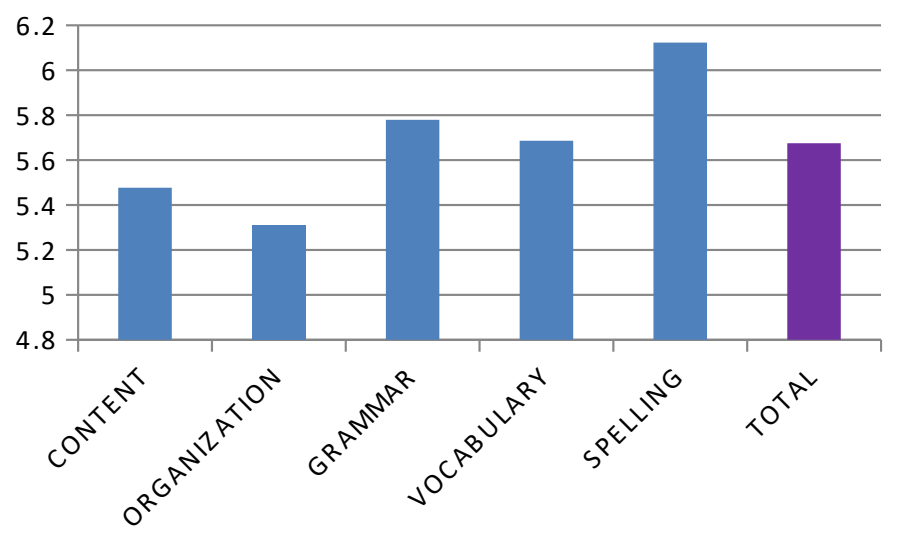

Fig. 3 Average outcomes of second written task

It is curious to observe that scores for spelling were still high, while the vocabulary variable reduced slightly in comparison with the first digital written task. Tentatively, this is because spelling has nothing to do with specific vocabulary within the field of business, which means that students do well with spelling whereas they do not manage to use specialized vocabulary in an adequate manner. As for the grammar variable, it can be observed that the scores on this second digital task were slightly lower than in the first one. It is possible that students did not manage to understand the specific business grammar constructions. Related to the organization variable, this graph above shows that students did not write their digital texts in both a cohesive and coherent manner since this variable decreased slightly. It should be mentioned, at this point, that these variables did not differ much throughout the experiment. This may be indicative that students have special difficulty creating cohesion and coherence when writing in English. However, in contrast to these variables, we can observe that the scores for content in this second digital written task were slightly lower here than in the first task. 


\subsubsection{Third Written Task}

In the third digital writing task, students wrote their final drafts, having received feedback from the teacher. The outcomes of this third online writing task can be seen in the figure below.

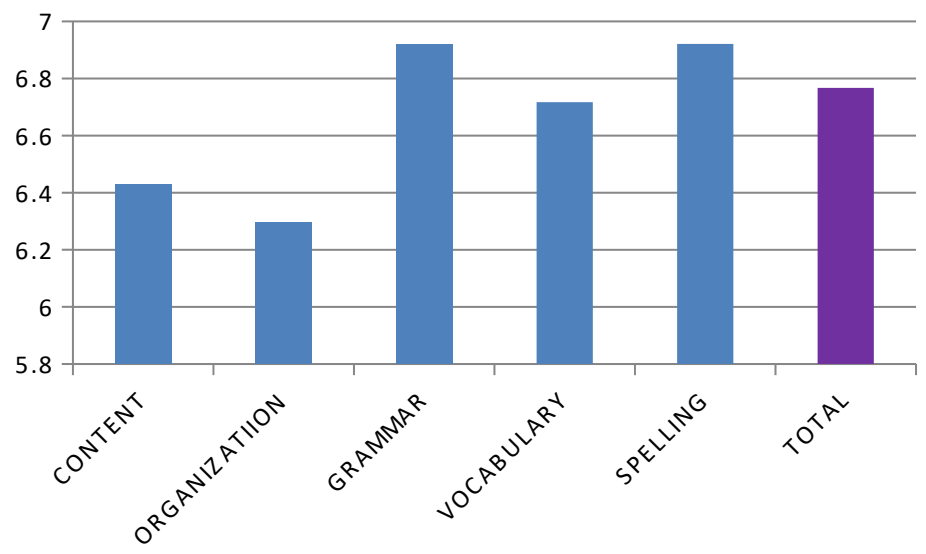

Fig. 4 Average outcomes of third written task

We can observe in the graph above that the highest marks on this third online written task were for spelling. In addition, compared with both the first and the second task, it can be clearly seen that this variable had improved notably. The fact that this variable was not difficult to master could be one reason why students improved notably on this variable. In the same line, the vocabulary also improved in this task in comparison with the previous tasks. After the second online task, and before starting the third task, students were required to review specialised vocabulary related to the field of business and, particularly, specific lexis on business plans. This may have influenced the fact that students did better on this third digital task with vocabulary. As for the grammar, it is interesting to note that students improved here slightly, when we compare outcomes with the two previous tasks. When we noticed that learners' marks decreased on the second digital task, we asked students to do further practice with specific business grammar constructions. Also, both coherence and cohesion improved slightly in comparison with the previous tasks, without reaching excellence. Before beginning with this task, students were asked to practice on the use of specific connectors, which helped students to improve the organization of the text. Lastly, the content variable also improved compared it with the previous tasks. This could be due to continuous practice on writing digitally their own business plan.

\subsection{Post-test}

Next, the outcomes of the post-test must be analyzed. The structure of the post-test was similar to the pre-test. In this post-test, learners had to write the final version of the business plan, having received feedback from the instructor. They were asked to check that the final product, that is, the definitive business plan, was structured in an adequate manner (Navarro, 2015). In the figure below, the outcomes of the post-test can be clearly observed. 


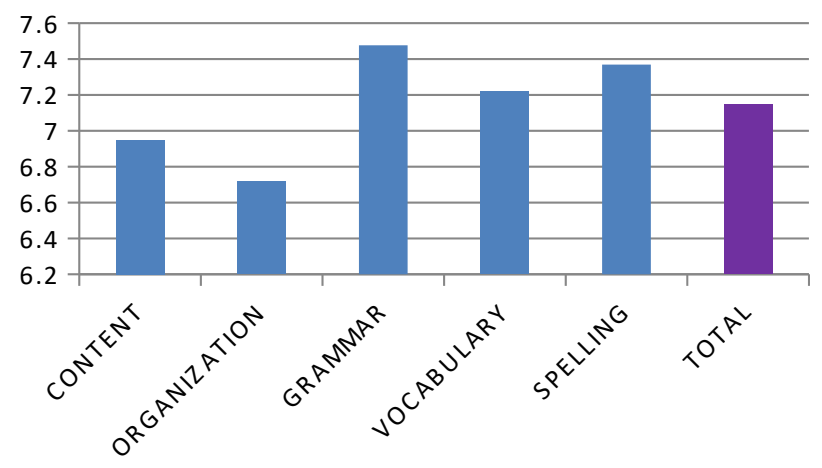

Fig. 5 Average outcomes of post-test task

Compared with the previous tasks, it is interesting that the grammar variable on this graph shows the highest outcomes. Moreover, comparing it with the previous tasks, this variable improved notably in the post-test. This may be indicative that students managed to understand how to use certain business grammar structures appropriately for their own business plan. What is more, in the post-test, the grammar mark appears slightly higher than the spelling mark, which fell to second place. Both vocabulary and spelling slightly improved in the post-test in comparison with the previous tasks. Between the second task and this one, we required students to keep practicing on the use of the specialized vocabulary in the field of business. Regarding the grammar, it is interesting to observe how this variable improved on the post-test. Finally, as for the organization variable, even though it increased slightly in comparison with the previous tasks, it seems that students still needed to do further practice on the use of connectors and, thus, they still did not manage to create digital texts in a cohesive manner while blogging.

\section{DISCUSSION}

This discussion will try to justify the different reasons for the outcomes throughout the whole experiment. Firstly, let us consider the pre-test. Grammar (4.9) and vocabulary (4.7) were the lowest marks, which could be due to the low level of learners studying in vocational training. Regarding the components content (5.17) and organization (5.13), learners seemed not to understand what the main aim of the pre-test was. Moreover, they did not comprehend that both coherence and cohesion were indeed important while writing a text, either a regular one or a digital one while blogging. The data from the pretest was important, even when the students did not produce what was expected, to understand how this current experiment evolved from the commencement to the end.

Secondly, the outcomes of the three main digital written production tasks will be justified. In the corresponding graph, where the average of the first written task is presented, it can be observed that learners improved in comparison with the pre-test. Concerning the organization component (5.8), learners seemed to understand the importance of writing a text divided into appropriate paragraphs, although their texts were not clear or easy to understand. As for the grammar component (6.1), a relevant improvement can be observed in comparison with the pre-test. Four previous sessions to reinforce grammar issues were 
given previous to this digital writing task. Likewise, the vocabulary component (6.2) also improved in comparison with the pre-test since learners revised, with the help of the teacher, key vocabulary related to the field of business, which was useful to complete the task well. These four reinforcement sessions were indeed necessary to help students improve, as a whole, their digital written competence while blogging.

Next, the outcomes of the second online production task will be tentatively justified. It can be observed that there is a slight decrease between the first digital writing task (6.17) and the second online writing task (5.6), which implies that there are no relevant differences in statistical terms between both tasks. This slight decrease in the second writing task could be due to either the low level of EFL ability in a relevant number of learners in vocational training, even though this aspect was considered initially in the research design to analyse how we could help these ESP learners in vocational training; or because of some difficulty that implies specific language use within the field of administration and management, such as the passive voice, relative pronouns, and superlative, among others. Learners of English in vocational training did not seem to understand that they should be aware of the importance of using specific language within the field of specialized English in the area of business and administration, although the instructor had previously explained the intended learning outcomes as well as the grading criteria. For this reason, the average of this second online writing task decreased notably in comparison with the first digital writing task.

The hypothetical reasons of the outcomes related to the third digital written task will be addressed. When learners were doing both the first and second task, it became clear that they did not know how to write a business plan, even in their mother tongue, which is Spanish. As for this issue, there was a lack of expertise among teachers on how to write business plans in Spanish. Therefore, we asked expert co-workers help to teach learners how to write their own business plans in their mother tongue. Five sessions were dedicated to training learners how to write their business plans. This specific training on writing their own business plans in Spanish helped learners to better the outcomes of this third written task. Therefore, the results of the third digital production task were notably higher than the outcomes of the second online production task. However, this suggests that it was the input which students received from these teacher colleagues that helped the students learn and, thus, it was not the use of blogs.

Having addressed the outcomes of both the first and the second task, there will now be a discussion of the possible reasons for the results of the post-test. In the post-test, learners had to write various texts related to various professional careers related to the field of Administration and Business Management. The main purpose of this task was to make it more authentic to learners taking into consideration the professional reality of learners and, thus, our main concern here was to adjust the various tasks of the experiment to learners' needs. This might be one of the reasons why the outcomes of the post-test were quite satisfactory. Having justified the various outcomes of the experiment, it is important to note that the outcomes were positive as initially expected before commencing the experiment.

It can therefore be stated that a high percentage of learners completed the post-test quite satisfactorily in comparison with the average of the pre-test. Therefore, it has been observed that the quantitative data have notably improved with regard to the competence in ESP written production. Both the pre-test as well as the post-test verify that there are positive and relevant differences in learning how to write in English for Administration and Management, within the Cooperative Learning Approach. 


\section{CONCLUSIONS}

Utilizing WordPress will allow ESP teachers at Vocational Training help their learners to improve their written competence. WordPress, as a blogging tool, helps learners to improve their written competence in foreign language learning. What is more, blogging makes the experience more meaningful and authentic since it encourages team learning, as well as collaborative work by learners in Internet. Overall, it can be said that learners' writing performance was improved with the use of WordPress and, thus, through blogging within the Cooperative Learning approach and, particularly, in Cooperative Writing at this experiment. In fact, the use of the blogs create more meaningful learning environment.

In light of the outcomes of this research, teachers of English for Specific Purposes at Vocational Training need to be conscious that blogging can be an effective method to help their learners to improve their writing scores. Teachers of EFL in Spain and, particularly, at non-university education need to be aware of the implications of this current research since it will offer them options in teaching their learners to write. Moreover, as this was only oneyear research, there is a need for longitudinal study looking at the development of written competence over a longer period of time, following learners for, at least, four years, which is the period formed by studies at Vocational Training in Spain.

Utilizing blogging as a tool for language learning actively encourages a Cooperative environment, builds positive attitude, augments motivation and learners' participation, and enhances teachers-students relationships (Mazer, Murphy \& Simonds, 2007). The teacher can enhance the use of WordPress by encouraging learners to follow updates from their colleagues in order to, lately, interact while blogging not only with their partners but also with other learners from other places worldwide.

In answer to the research question on whether blogging can improve competence in ESP written production and, particularly, within the field of English related to Administration and Management according to the Cooperative Learning Approach, from the data obtained in the post-test it can be observed that in this study competence in written production improved quite notably. Therefore, considering the information provided in the previous section, it seems reasonable to conclude that the students may have learnt and improved their ESP writing skills due to the use of the blogs at this experiment. However, it must be mentioned that learners were exposed to preparation sessions that helped them perform better in their blogging tasks.

To conclude, given that the existing references (Montaner-Villalba, 2016, 2017) related to blogging in teaching ESP in vocational training are scarce, even with the inclusion of active educational methodologies (Montaner-Villalba, 2019b), this current paper offers initially worthwhile and significant value within the field of technology-enhanced language learning applied to English for Specific purposes in vocational training through the use of active educational methodologies. At any case, the results of this research might provide a strong argument for further empirical research on the use of blogging in teaching English for Specific Purposes in vocational training with the inclusion of diverse active teaching methods. 


\section{REFERENCES}

Aghajani, Motjaba \& Mahsa Adloo (2018). "The Effect on Online Cooperative Learning on Students' Writing Skills and Attitudes through Telegram Application", International Journal of Instruction, 11 3(2018): 433-448. Accessed 10 October, 2020. DOI: https://doi.org/10.12973/iji.2018.11330a

Akıllı, Erman, Lesia Konoplianyk and Yuliia Pryshupa. "ICT in Teaching ESP to Future Civil Engineers at Technical University," Advanced Education 6, 11 (2019): 93-99. Accessed 19 July, 2020, DOI:10.20535/2410-8286.148507.

Awada, Ghada, and Ghazi Ghaith. "Effect of Using the Blog Educational Tool on Writing Achievement and Motivation for Legal Writing". International Journal of Education and Research, 212 (2014): 371-388. Accessed 10 July, 2018.

Bran, Ramona. "Do the Math: ESP + Web 2.0=ESP2.0!", Procedia Social and Behavioral Sciences 1 (2009): 2219-2523. Accessed 23 May, 2019.

Campbell, Aaron P. "Weblog applications for EFL/ESL classroom blogging: A comparative review". TESL-EJ, 93 (2005). Accessed 20 January, 2012.

Campbell, Aaron P. "Using LiveJournal for authentic communication in EFL classes". The Internet TESL Journal, 109 (2004): 64-68. Accessed 01 May, 2012.

Campbell, Aaron P. "Weblogs for use with ESL classes". The Internet TESL Journal, 92 (2003): 33-35. Accessed 01 May, 2012.

Carney, Nat. "Blogging in foreign language education". In Handbook of research on web 2.0 and second language learning, edited by Michael Thomas, 292-312, New York: IGI Global, 2009a.

Carney, Nat. "Language study through blog exchanges". Wireless Ready Symposium eProceedings Japan. Accessed 20 March, 2014. http://wirelessready.nucba.ac.jp/Carney. pdf, 2009b

Carney, Nat. "Blogging in foreign language education". In Handbook of research on web 2.0 and second language learning, edited by Michael Thomas, 292-312, Hershey and New York: Information Science Reference, 2008

Carney, Nat. "Language study through blog exchanges". Wireless Ready Symposium: Podcasting Education and Mobile Assisted Language Learning, 2007: 109-120

Domingo-Coscolla, María, Joan Anton Sánchez-Valero, and Juana Ma Sancho-Gil. 2014. "Investigar con y sobre los jóvenes colaborando y educando". Comunicar, 4221 (2014): 157-164. Accessed 20 June, 2020. DOI:10.3916/c42-2014-15

Ducate, Lara C. and Lara L. Lomicka. "Exploring the blogosphere: Use of web logs in the foreign language classroom”. Foreign Language Annals, 383 (2005): 410-421. Accessed 12 April, 2010. DOI: https://doi.org/10.1111/j.1944-9720.2005.tb02227.x

Fellner, Terry and Mathew Apple. "Developing writing fluency and lexical complexity with blogs". The JALT Call Journal, 21 (2006): 15-26

Ghomari, Soraya Halfaoui. "Bridging the communicative competence gap of the English language in the workplace through an ICT-ESP based approach of teaching in Algeria", Procedia - Social and Behavioral Sciences, 199 (2015): 756-762. Accessed 03 November, 2018. DOI: https://doi.org/10.1016/j.sbspro.2015.07.608

Godwin-Jones, Robert. "Blogs and wikis: Environments for online collaboration”. Language Learning \& Technology, 72 (2003): 12-16

Gómez-Pezuela Gamboa, Guadalupe. Desarrollo psicológico y aprendizaje. México: Trillas, 2007 
Gufrhon, M. Ali \& Siti Ermawati. "The Strengths and Weaknesses of Cooperative Learning and Problem-Based Learning in EFL Writing Class: Teachers and Students' Perspectives". International Journal of Instruction, 114 (2018): 657-672. Accessed 10 October, 2020.

Hernández-Sellés, Nuria, Mercedes González-Sanmamed, and Pablo C. Muñoz-Carril. "La planificación del aprendizaje colaborativo en entornos virtuales". Comunicar, 2142 (2014): 25-33. Accessed 14 April, 2018. DOI:10.3916/c42-2014-02

Hertiki, Hertiki and Juliati Juliati. "Improving students' writing skills using Cooperative Learning at SMPN 2 SUKODONO”. Journal of English for Academic and Specific Purposes, 22 (2019): 36-56. Accessed 10 October, 2020. DOI: https://doi.org/10.18860/ jeasp.v2i2.7853

Jones, Zachary and Bernice Nuhfer-Halten. "Uses of blogs in L2 instruction". In Selected Proceedings of the 2006 Joint Conference of the Southern Conference on Language Teaching and the Florida Foreign Language Association, edited by C. Maurice Cherry, 25-35, Roswell, GA: Valdosta State University, 2006.

Johnson, David W. and Roger T. Johnson. La Evaluación en el aprendizaje cooperativo (Biblioteca Innovación Educativa), Madrid: SM. 2016

Kagan, Michael, Louise Robertson, and Spencer Kagan. Cooperative Learning Structures for Classbuilding, San Clemente, CA: Kagan Publishing. 1995

Kagan, Spencer. Cooperative Learning. San Clemente, CA: Kagan Publishing. 2009

Lázaro, Raquel, Carmen Pena, and Bianca Vitalaru. "Wikis en lenguas para fines específicos y su traducción". Red U - Revista de Docencia Universitaria. Monograph V in co-edition with Revista de Educación a Distancia (RED). (2009): 1-22. Accessed 02 April 2014. http://www.um.es/ead/Red_U/m5/

Mahmoud, Montasser Mohammed AbdelWahab. "The effectiveness of Using the Cooperative Language Learning Approach to Enhance EFL writing skills among Saudi University Students". In Journal of Language Teaching and Research, 53 (2014): 616625, DOI: 10.4304/jltr.5.3.616-625

Martín-Monje, Elena. "Interactive Materials, Collaborative Work and Web 2.0 in the context of ESP". In Technological Innovation in the Teaching and Processing of LSPS: Proceeding of TISLID'10, edited by Noa Talaván Zanón, Elena Martín-Monje and Francisco Palazón Romero, 101-113, Madrid: UNED, 2010

Mazer, Joseph P., Richard E. Murphy \& Cheri J. Simonds. "I'll see you on Facebook: the effects of Computer-Mediated Teacher Self-Disclosure on Student Motivation, Affective Learning, and Classroom Climate”. Journal Communication Education, 561 (2007): 117. DOI: $10.1080 / 03634520601009710$

Montaner-Villalba, Salvador. "La competencia en producción escrita en lengua inglesa mediante el blogging en un entorno de aprendizaje cooperativo en la Enseñanza Secundaria Obligatoria". E-SEDLL, 3 (2020a): 158-171.

Montaner-Villalba, Salvador. "Written Production in EFL through blogging and cooperative learning at A-level”, Tejuelo, 31 (2020b): 97-118. DOI: 10.17398/1988-8430.31.97

Montaner-Villalba, Salvador. "La producción escrita en la enseñanza del inglés para fines específicos mediante el Blogging: análisis del rango de la producción escrita". In Focus on Learning: Contributions to the field of ESP, edited by Cristina Calle-Martínez and Slavka Madarova, 19-26, Madrid: UCJC, 2019a 
Montaner-Villalba, Salvador. "Competencia en producción escrita en inglés para fines específicos mediante el Blogging en un entorno de Aprendizaje Basado en Proyectos". Revista de Lenguas para fines específicos, 252 (2019b): 173-192, DOI: http://dx.doi.org/ 10.20420/rlfe.2019.292

Montaner-Villalba, Salvador. "La competencia en producción escrita del inglés técnico mediante el Blogging". Verbeia. Monograph: Language Teaching and Multilingual Education. (2017): 84-102

Montaner-Villalba, Salvador. "La competencia en producción escrita del inglés técnico mediante el Blogging (Investigación-Acción)". Actas del I Congreso Internacional de Enseñanza del Inglés en Centros Educativos, (2016): 233-242

Murray, Liam, and Tríona Hourigan. "Blogs for specific purposes: Expressivist or sociocognitivist approach?”. ReCALL, 201 (2008): 82-97. DOI: https://doi.org/10.1017/ S0958344008000719

Nair, Subadrah M. \& Mogana Sanai. "Effects of utilizing the STAD Method (Cooperative Learning Approach) in Enhancing Students' Descriptive Writing Skills". International Journal of Education and Practice, 64 (2018): 239-252. DOI: 10.18488/journal.61.2018. 64.239 .252

Navarro, Federico, Y. "Business plan: A preliminary approach to an unknown genre." Ibérica, Revista de la Asociación Europea de Lenguas para Fines Específicos, no. 30 (2015):129-153. Redalyc, https://www.redalyc.org/articulo.oa?id=287042542007

Patel, Tarun. "Analyzing the Impact of Blogging on Writing and Grammar Editing Skills of Engineering Students", International Journal of Humanities in Technical Education, 12 (2015). Accessed 19 July, 2020.

Pinkman, Kathleen. "Using blogs in the foreign language classroom: Encouraging learner independence". The JALT CALL Journal, 11 (2005): 12-24. Accessed 14 April, 2014. DOI: https://doi.org/10.29140/jaltcall.v1n1.2

Pujolàs, Pere. Aprender juntos alumnos diferentes (Recursos). Barcelona: Octaedro. 2017

Shehadeh, Ali. "Effects and student perceptions of collaborative writing in L2". Journal of Second Language Writing, 204 (2011): 286-305. Accessed 28 November, 2017. DOI: https://doi.org/10.1016/j.jslw.2011.05.010

Sevillano García, M ${ }^{\mathrm{a}}$ Luisa and Esteban Vázquez Cano. Educadores en Red. Elaboración y Edición de materiales audiovisuales para la enseñanza. Madrid: Ediciones AcadémicasUNED. 2011 